\title{
Pengembangan Multimedia Pembelajaran Interaktif Autoplay Media Studio pada Materi Struktur Atom
}

\section{Development of Interactive Instructional Multimedia Autoplay Media Studio on Atomic Structure Lesson}

\author{
Siti Ayu Punisah ${ }^{*}$, Lazulva ${ }^{1}$, Lisa Utami ${ }^{1}$ \\ ${ }^{1}$ Program Studi Pendidikan Kimia Fakultas Tarbiyah dan Keguruan, Universitas Islam Negeri Sultan Syarif \\ Kasim Riau, Pekanbaru, Indonesia
}

\section{A B S T R A K}

Tujuan dilakukan penelitian ini yaitu untuk menghasilkan media pembelajaran multimedia interaktif pada materi struktur atom dengan menggunakan software Autoplay Media Studio. Metode penelitian yang digunakan adalah metode Research and Development (R\&D) dengan menggunakan model pengembangan 4D (Define, Design, Development, and Disseminate). Penelitian dilakukan di SMK Abdurrab Pekanbaru. Subjek penelitian adalah 2 orang validator (ahli materi dan ahli media), 3 orang guru kimia dan 10 orang peserta didik kelas X TLM 1. Instrumen pengumpulan data pada penelitian ini berupa angket uji validitas dan angket uji praktikalitas. Data yang diperoleh kemudian dianalisis dengan teknik analisis deskriptif kualitatif dan kuantitatif. Media pembelajaran yang dihasilkan memiliki tingkat validitas oleh ahli materi sebesar 91,29\% (sangat valid), ahli media sebesar 90,04\% (sangat valid), dan tingkat praktikalitas oleh guru sebesar 88,92\% (sangat praktis), respon peserta didik sebesar 90,15\%. Berdasarkan hasil tersebut disimpulkan bahwa media pembelajaran kimia menggunakan multimedia interaktif Autoplay Media Studio pada materi struktur atom sudah valid dan praktis untuk dijadikan media pembelajaran alternatif di sekolah.

\section{A B STR A C T}

This research aimed at developing an interactive multimedia instructional media that was valid and practical on Atomic Structure lesson, and it was designed by using Autoplay Media Studio Software. It was $R \& D$ (Research and Development) with 4-D (Define, Design, Develop, Disseminate) model. It was administered at Vocational High School of Abdurrab Pekanbaru. The subjects of this research were two validators (material and media experts), three Chemistry teachers, and ten students at tenth grade of TLM 1. Instruments of collecting the data were in the forms of validity and practicality test questionnaires. The obtained data then were analyzed by using qualitative and quantitative descriptive analysis techniques. The developed instructional media had $91.29 \%$ validity level (very valid) by the material expert, $90.04 \%$ validity level (very valid) by the media expert, $88.92 \%$ practicality level (very practical) by the teachers, and 90.15\% practicality level by students. Based on these results, it could be concluded that Chemistry instructional media using Autoplay Media Studio Interactive Multimedia on Atomic Structure lesson was valid and practical to be an alternative instructional media at a school.

Kata kunci : Media pembelajaran; multimedia interaktif, software autoplay media studio, struktur atom

Keyword : Instructional Media; Interactive Multimedia; Autoplay Media Studio Software; Atomic Structure

I N F O A R T I K E L

\begin{tabular}{l|l}
\hline Received: 14 Oktober 2019; & * coresponding author: sitiayupunisah@gmail.com \\
Revised: 09 Mar 2020; & DOI: https://doi.org/10.22437/jisic.v12i1.7829 \\
Accepted: 14 May 2020 &
\end{tabular}




\section{PENDAHULUAN}

Perkembangan ilmu pengetahuan dan teknologi saat ini telah berkembang begitu pesat dalam segala aspek kehidupan, khususnya di bidang teknologi informasi dan komunikasi. Seiring berkembangnya teknologi secara langsung menuntut dunia pendidikan untuk menyesuaikan perkembangan tersebut dalam meningkatkan mutu pendidikan sehingga menciptakan sumber daya manusia yang berkualitas. Manusia adalah pengguna teknologi yang mampu memanfaatkan teknologi saat ini, maupun perkembangan teknologi selanjutnya. Manusia juga harus beradaptasi dengan teknologi baru yang berkembang melalui pendidikan. Pada akhirnya teknologi dan pendidikan dapat berkembang bersamaan seiring seirama (Nu'aimah, 2016).

Seiring dengan pentingnya ilmu pengetahuan dan teknologi, dibutuhkan suatu peningkatan mutu. Peningkatan mutu pendidikan dapat dilakukan dengan mengadakan pembaharuan pada komponen dalam proses belajar. Pembaharuan atau inovasi ini salah satunya dapat dilakukan dengan membuat suatu alat bantu pada proses pembelajaran. Bagi dunia pendidikan, perkembangan teknologi ini merupakan suatu inovasi yang mampu menawarkan keefektifan dalam proses belajar mengajar yang terimplementasi dalam suatu bentuk media pembelajaran yang berbasis teknologi dan informasi, hal tersebut menjadikan proses pembelajaran lebih menarik dan inovatif.

Media merupakan alat bantu dalam kegiatan belajar mengajar. Alat bantu dapat mewakili sesuatu yang tidak dapat disampaikan guru melalui kata-kata atau kalimat. Keefektifan daya serap peserta didik terhadap bahan pelajaran yang sulit dan rumit dapat dipermudah dengan adanya penggunaan alat bantu. Bahkan alat bantu tersebut diakui dapat melahirkan umpat balik yang baik dari peserta didik. Media pembelajaran yang digunakan diharapkan dapat membuat peserta didik memahami materi pembelajaran yang disampaikan oleh guru dan dapat menarik perhatian peserta didik seperti penggunaan media pembelajaran dengan multimedia interaktif (Nisa, 2017).

Setiap materi pelajaran selalu terkait dengan media pembelajaran baik dari yang berbentuk sederhana sampai pada bentuk yang paling kompleks. Mata pelajaran kimia salah satunya, karakteristik ilmu kimia yang membutuhkan pemahaman konsep menjadikan peserta didik beranggapan bahwa pelajaran kimia merupakan pelajaran yang sulit. Oleh sebab itu, pada mata pelajaran kimia membutuhkan media atau alat bantu guna meningkatkan pemahaman pada peserta didik. Struktur atom adalah salah satu materi kimia yang berisikan konsep-konsep abstrak seperti elektron, neutron, atom, proton dan lain-lain. Konsep ini merupakan konsep dasar dalam setiap mempelajari materi kimia baik di jenjang SMA maupun kimia di Universitas. Untuk itu diperlukan adanya upaya untuk membuat konsep-konsep abstrak tersebut menjadi konkrit. Salah satunya dengan menggunakan media pembelajaran yang memuat gambar maupun animasi (Auliah, 2010).

Berdasarkan wawancara dengan guru bidang studi kimia di SMK Abdurrab Pekanbaru, diperoleh informasi bahwa pelaksanaan pembelajaran pada kelas $\mathrm{X}$ sudah menyesuaikan dengan kurikulum 2013. Media pembelajaran yang digunakan dalam proses pembelajaran berupa powerpoint, lembar kerja peserta didik, buku paket dan papan tulis. Media pembelajaran yang digunakan pada materi struktur atom di SMK Abdurrab Pekanbaru belum bisa memvisualisasikan materi struktur atom yang bersifat abstrak. Penggunaan media pembelajaran berbasis komputer pada materi ini dirasa akan lebih efisien. Hal ini dikarenakan salah satu kelebihan dari penggunaan komputer sebagai media pembelajaran adalah dapat menjelaskan materi kimia yang berisikan abstrak menjadi lebih konkrit dan materi dapat dipelajari secara berulang-ulang.

Autoplay media studio merupakan aplikasi untuk membuat perangkat lunak (software) multimedia dengan mengintegrasikan berbagai tipe media 
misalnya gambar, suara, video, teks dan flash ke dalam presentasi yang dibuat dengan cepat. Autoplay media studio selain canggih juga banyak digunakan karena lebih mudah dan memiliki kualitas media pembelajaran yang sangat bagus (Wijaya \& Rakhmawati, 2015).

\section{METODE PENELITIAN}

Penelitian ini menggunakan metode penelitian dan pengembangan Research and Development (R\&D). Penelitian dan pengembangan dilakukan pada bulan Mei sampai dengan 8 November 2018. Objek penelitian ini adalah media pembelajaran menggunakan multimedia interaktif autoplay media studio pada materi struktur atom kelas X SMK Sederajat. Subjek dalam penelitian ini adalah pihak yang melakukan validasi terhadap produk media pembelajaran menggunakan multimedia interaktif autoplay media studio yang dihasilkan yaitu ahli media pembelajaran, ahli materi pembelajaran, guru kimia dan peserta didik di SMK Abdurrab Pekanbaru. Populasi dalam penelitian ini adalah 160 orang peserta didik kelas X SMK Abdurrab Pekanbaru. Sampel dalam penelitian ini adalah 3 orang guru kimia di SMK Abdurrab Pekanbaru dan 10 orang peserta didik kelas X TLM 1 SMK Abdurrab Pekanbaru.

Pada penelitian ini menggunakan model 4-D yang direkomendasikan oleh Thiagarajan. Model Penelitian 4-D terdiri atas 4 tahap yaitu: define (pendefenisian), design (perancangan), development (pengembangan), and dissemination (penyebarluasan). Namun, pada penelitian ini peneliti hanya melakukan penelitian sampai pada tahap ketiga yaitu tahap development bagian revisi dari uji coba produk.

Pembuatan media pembelajaran terlebih dahulu divalidasi oleh ahli media pembelajaran. Instrumen ini divalidasi oleh 1 orang ahli media. Penilaian instrumen disusun menurut skala bertingkat (rating scale). Pembuatan media pembelajaran terlebih dahulu divalidasi oleh ahli materi pembelajaran. Instrumen ini divalidasi oleh 1 orang ahli materi.

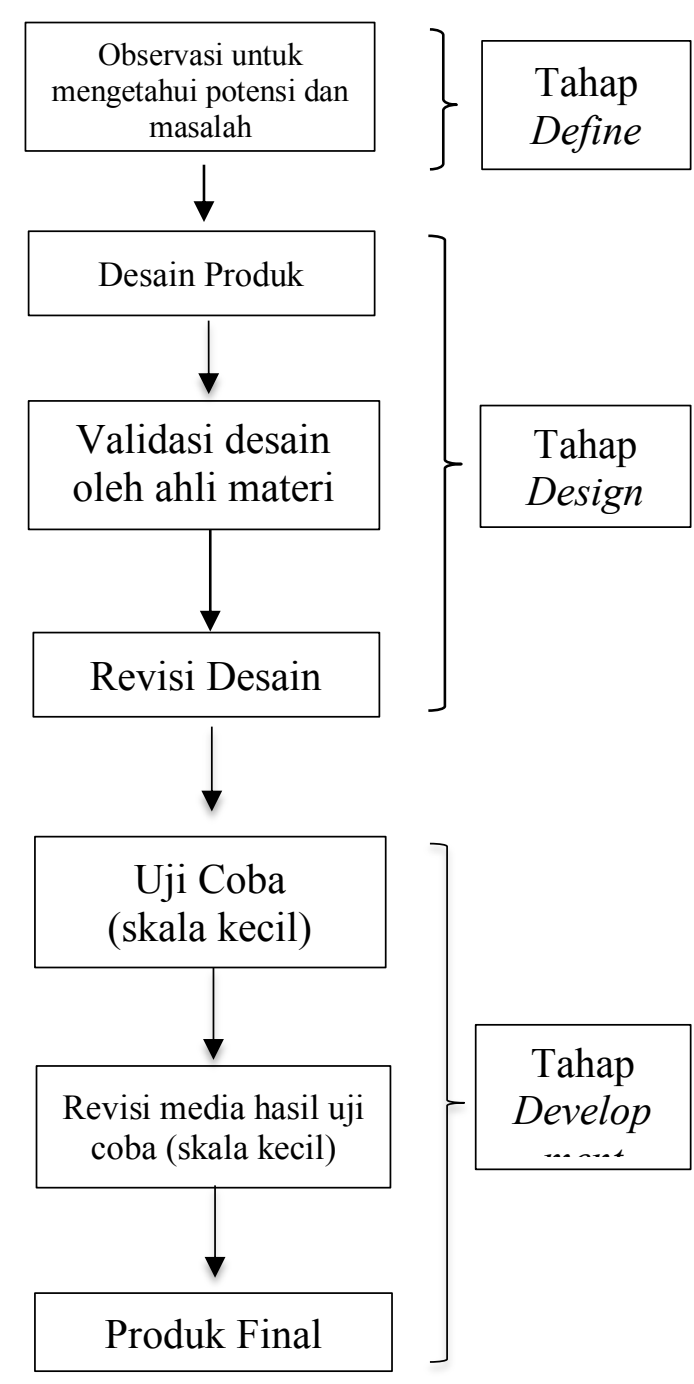

Gambar 1. Skema alur penelitian

Teknik analisis data yang digunakan adalah teknik analisis deskriptif kualitatif dan teknik analisis deskriptif kuantitatif yang mendeskripsikan hasil uji validitas dan uji praktikalitas. Untuk melakukan analisis validitas media pembelajaran yang dikembangkan digunakan rating scale dengan cara membagi skor yang diperoleh dengan skor maksimal kemudian dikali dengan $100 \%$.

Hasil persentase praktikalisasi kemudian ditafsirkan dalam pengertian kualitatif berdasarkan pada tabel 2 . 
Tabel 1. Skala angket validasi oleh ahli media dan ahli materi

\begin{tabular}{ll}
\hline Interval & Kriteria \\
\hline $81 \%-100 \%$ & Sangat Valid \\
$61 \%-80 \%$ & Valid \\
$41 \%-60 \%$ & Cukup Valid \\
$21 \%-40 \%$ & Kurang Valid \\
$0 \%-20 \%$ & Tidak Valid \\
\hline
\end{tabular}

\section{HASIL DAN PEMBAHASAN}

Penelitian dan pengembangan ini menggunakan model pengembangan $4 \mathrm{D}$ yang memiliki 4 tahapan yaitu Define (pendefinisan), Design (perancangan), Develop (pengembangan) dan Dissemintae (penyebaran), akan tetapi hanya dilakukan sampai tahap ketiga yaitu sampai pada pengembangan produk, dimana peneliti hanya mendesain serta melakukan uji coba media pembelajaran skala kecil.

\section{Tahap Pendefinisian}

Tahap define atau pendefinisian merupakan tahapan awal dari model pengembangan 4-D. Pada tahap ini dilakukan suatu analisis tujuan. Analisis tujuan adalah hal paling awal yang harus dilakukan karena pada kriteria pemilihan media pembelajaran, kesesuaian dengan tujuan merupakan kriteria pertama yang harus diperhatikan dalam pemilihan media. Setelah dilakukan analisis tujuan selanjutnya akan dilakukan perancangan dari desain media pembelajaran menggunakan autoplay media studio.

\section{Tahap Desain}

Tahap desain merupakan tahap kedua dari proses pengembangan setelah tahap pendefinisian yang telah dilakukan di awal. Pada tahap desain, dilakukan desain produk sebagai dasar untuk tahap pendembangan berikutnya Secara umum, desain pengembangan media pembelajaran menggunakan multimedia interaktif autoplay media studio pada materi struktur atom ini dapat dilihat pada gambar 2 sampai dengan gambar 5.

\section{Desain halaman intro dan selamat datang}

Halaman intro dan ucapan selamat datang merupakan halaman paling awal dari media pembelajaran ini. Desain halaman intro dan ucapan selamat datang dapat dilihat seperti pada gambar 2 .

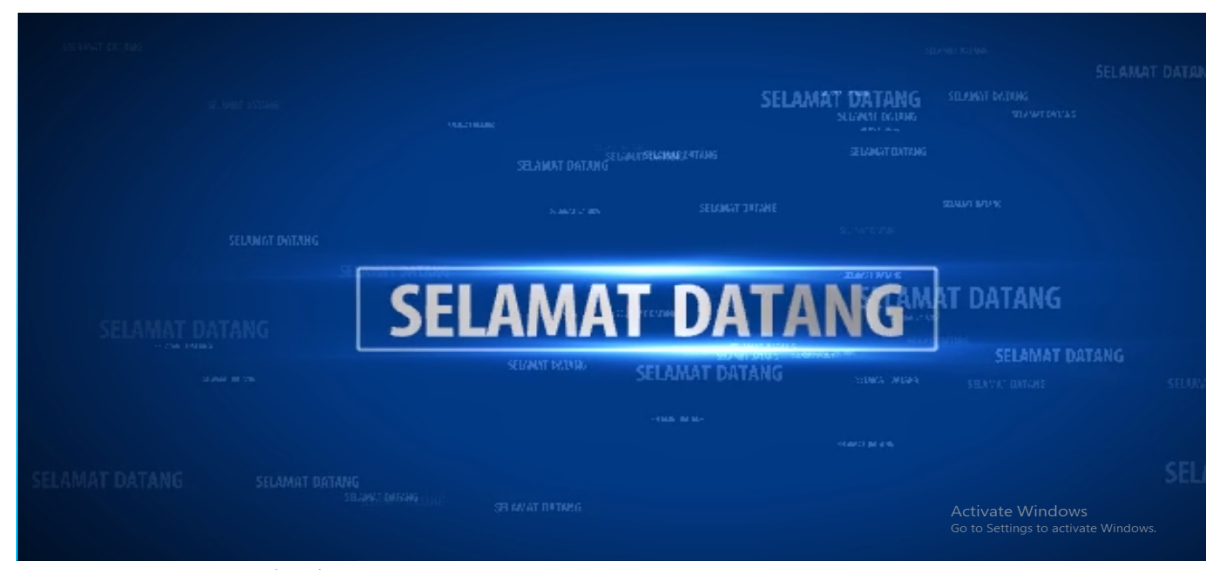

Gambar 2. Desain intro

\section{Desain halaman awal}

Pada halaman awal, disajikan hal-hal apa saja yang pengguna dapat lakukan pertama kali, seperti pilih backsound music, buka menu utama, dan keluar. Desain halaman awal dapat dilihat seperti pada gambar 3 . 


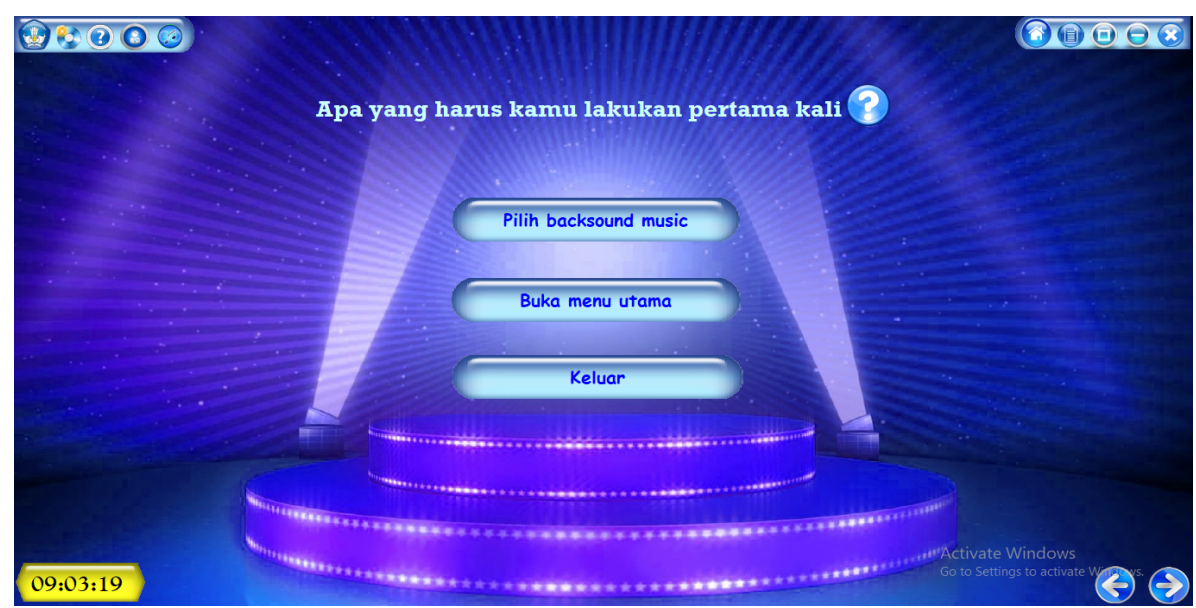

Gambar 3. desain awal

\section{Desain halaman menu}

Pada halaman menu, disajikan hal-hal apa saja yang pengguna bisa dapatkan dalam media pembelajaran. Menu utama ini terdiri atas submenu petunjuk penggunaan, kurikulum, materi ajar, evaluasi pembelajaran, referensi, dan profil perancang media pembelajaran. Desain halaman menu dapat dilihat pada gambar 4 .

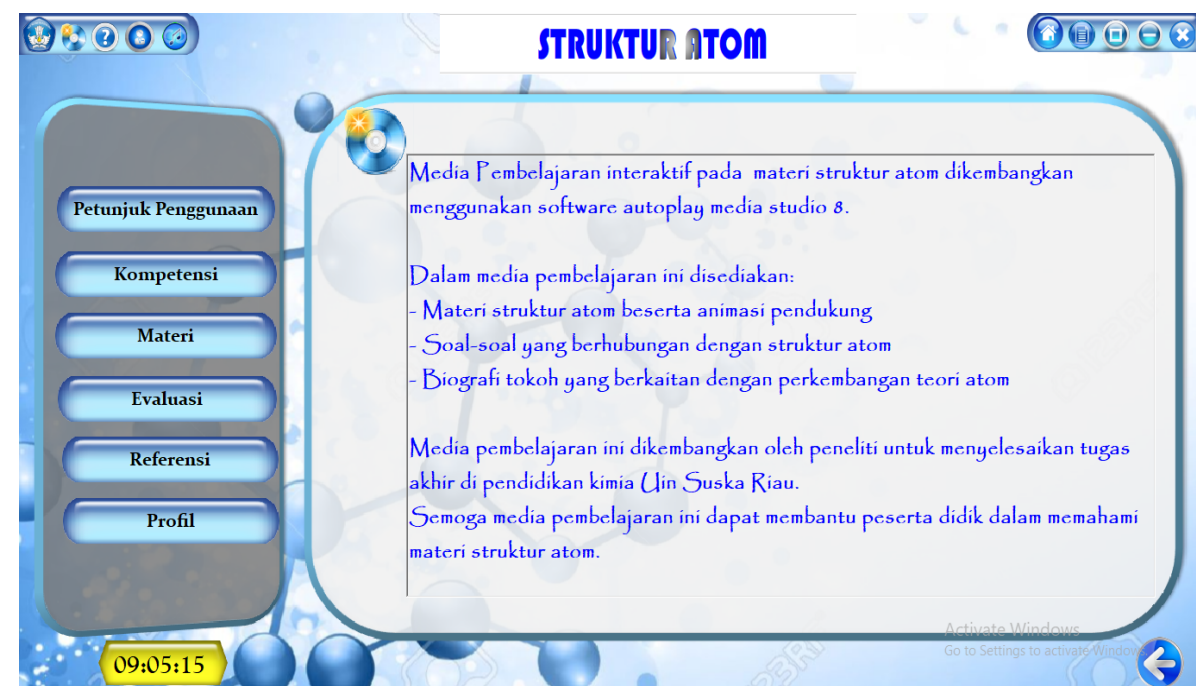

Gambar 4. Desain halaman menu

\section{Desain halaman evaluasi pembelajaran}

Pada halaman evaluasi pembelajaran terdapat evaluasi pembelajaran yang memuat soal-soal mengenai struktur atom untuk menguji pemahaman peserta didik setelah belajar di menu materi. Desain halaman evaluasi pembelajaran dapat dilihat seperti pada gambar 5 . 


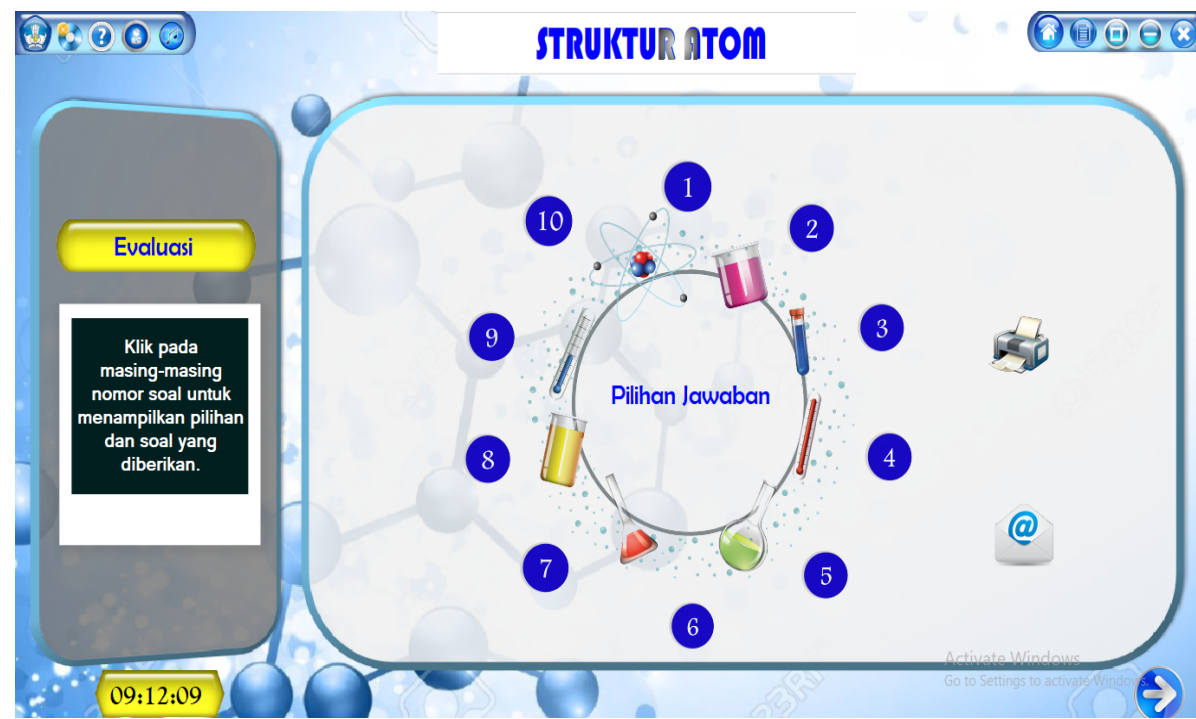

Gambar 5. Desain halaman evaluasi

\section{Tahap Pengembangan}

Setelah dilakukan desain selanjutnya dilakukan pengembangan sesuai dengan rancangan awal yang telah dilakukan pada tahap desain. Setelah media selesai dikembangkan selanjutnya dilakukan uji validitas isi berupa uji ahli materi dan uji ahli media. Validasi ahli materi bertujuan untuk menilai kelengkapan materi, kebenaran materi, dan sistematika materi. Hasil dari validitas ahli materi dapat dilihat seperti pada tabel 2 .

Tabel 2. Hasil validasi media pembelajaran oleh ahli materi

\begin{tabular}{llllll}
\hline \multirow{2}{*}{ Jenis Angket } & Aspek & $\begin{array}{l}\text { Nomor } \\
\text { Indikator }\end{array}$ & Skor & $\begin{array}{l}\text { Nilai } \\
\text { Validitas }\end{array}$ & Kriteria \\
\hline $\begin{array}{l}\text { Angket Penilaian } \\
\text { Ahli Materi }\end{array}$ & Kelayakan isi & $\begin{array}{l}1,2,3,4,5,6, \\
7,8,9\end{array}$ & 43 & $95,55 \%$ & $\begin{array}{l}\text { Sangat } \\
\text { Valid }\end{array}$ \\
\cline { 2 - 6 } & $\begin{array}{l}\text { Kelayakan } \\
\text { penyajian }\end{array}$ & $10,11,12$ & 14 & $93,33 \%$ & $\begin{array}{l}\text { Sangat } \\
\text { Valid }\end{array}$ \\
\cline { 2 - 6 } & Kebahasaan & $13,14,15,16$ & 18 & $85 \%$ & $\begin{array}{l}\text { Sangat } \\
\text { Valid }\end{array}$ \\
\hline & Jumlah & $\mathbf{7 5}$ & $\mathbf{9 1 , 2 9 \%}$ & $\begin{array}{l}\text { Sangat } \\
\text { Valid }\end{array}$ \\
\hline
\end{tabular}

Dari hasil validitas ahli materi dapat diketahui bahwa, dari tiga aspek yang dinilai yaitu kelayakan isi, kelayakan penyajian dan kebahasaan semuanya mendapatkan penilaian sangat valid dengan nilai validitas secara berurutan yaitu $95,55 \%, 93,33 \%$ dan $85 \%$.

Setelah dilakukan validitas ahli materi selanjutnya dilakukan validasi ahli media yang bertujuan untuk menilai penyajian media pembelajaran dilihat dari aspek tampilan dan pemrograman. Hasil validitas ahli media terhadap dua aspek yang dinilai yaitu aspek tampilan mendapatkan nilai validitas $90.90 \%$ dan aspek pemrograman mendapatkan nilai $89.18 \%$ dengan kriteria sangat valid. Data hasil validitas ahli media dapat dilihat seperti pada tabel 3. 
Tabel 3. Hasil validasi media pembelajaran oleh ahli media

\begin{tabular}{llllll}
\hline \multirow{2}{*}{ Jenis Angket } & Aspek & Nomor Indikator & Skor & $\begin{array}{l}\text { Nilai } \\
\text { Validitas }\end{array}$ & Kriteria \\
\hline $\begin{array}{l}\text { Angket Penilaian } \\
\text { Ahli Media }\end{array}$ & Tampilan & $\begin{array}{l}1,2,3,4,5,6,7, \\
8,9,10,11\end{array}$ & 50 & $90,90 \%$ & $\begin{array}{l}\text { Sangat } \\
\text { Valid }\end{array}$ \\
\cline { 2 - 6 } & Pemrograman & $\begin{array}{l}12,13,14,15,16, \\
17,18\end{array}$ & 33 & $89,18 \%$ & $\begin{array}{l}\text { Sangat } \\
\text { Valid }\end{array}$ \\
\hline & & $\mathbf{8 3}$ & $\mathbf{9 0 , 0 4 \%}$ & $\begin{array}{l}\text { Sangat } \\
\text { Valid }\end{array}$ \\
\hline
\end{tabular}

Setelah dilakukan validitas ahli materi dan ahli media selanjutnya dilakukan uji praktikalisasi media. Hasil penilaian uji praktikalitas media pembelajaran oleh guru kimia dapat dilihat pada tabel 4 .

Tabel 4. Hasil uji praktikalitas media pembelajaran oleh guru

\begin{tabular}{|c|c|c|c|c|c|}
\hline Jenis Angket & Aspek & $\begin{array}{l}\text { Nomor } \\
\text { Indikator }\end{array}$ & Skor & $\%$ & Kriteria \\
\hline \multirow[t]{3}{*}{$\begin{array}{l}\text { Angket Penilaian Uji } \\
\text { Praktikalitas Guru }\end{array}$} & Pembelajaran & $\begin{array}{l}1,2,3,4,5, \\
6\end{array}$ & 80 & $\begin{array}{l}88,89 \\
\%\end{array}$ & $\begin{array}{l}\text { Sangat } \\
\text { Praktis }\end{array}$ \\
\hline & Materi & $7,8,9,10,11$ & 67 & $\begin{array}{l}89,33 \\
\%\end{array}$ & $\begin{array}{l}\text { Sangat } \\
\text { Praktis }\end{array}$ \\
\hline & Tampilan & $\begin{array}{l}12,13,14, \\
15,16,17, \\
18\end{array}$ & 93 & $\begin{array}{l}88,56 \\
\%\end{array}$ & $\begin{array}{l}\text { Sangat } \\
\text { Praktis }\end{array}$ \\
\hline Jumlah & & & 240 & $\begin{array}{l}88,92 \\
\%\end{array}$ & $\begin{array}{l}\text { Sangat } \\
\text { Praktis }\end{array}$ \\
\hline
\end{tabular}

Dari tabel 4 dapat diketahui bahwa media pembelajaran yang dikembangkan mendapatkan penilaian sangat praktis dari guru kimia pada aspek pembelajaran, materi dan tampilan.

Hasil yang sama juga dapat dilihat dari respon peserta didik terhadap media pembelajaran yang dikembangkan dimana untuk aspek pembelajaran, materi dan tampilan masing-masing mendapatkan persentase kepraktisan sebesar 91,33\%, 90\% dan $89 \%$. Hasil respon peserta didik dapat dilihat pada tabel 5 .

Tabel 5. Hasil respon peserta didik

\begin{tabular}{llll}
\hline Aspek & Nomor Indikator & Skor & Persentase (\%) \\
\hline Pembelajaran & $1,2,3,4,5,6$ & 274 & $91,33 \%$ \\
Materi & $7,8,9,10,11$ & 225 & $90 \%$ \\
Tampilan & $12,13,14,15,16,17,18$ & 312 & $89,13 \%$ \\
\hline Jumlah & & $\mathbf{8 1 1}$ & $\mathbf{9 0 , 1 5 \%}$ \\
\hline
\end{tabular}

Berdasarkan validasi ahli materi dan media serta uji kepraktisan dapat diketahui bahwa media yang dikembangkan sudah sangat baik dan dapat dilanjutkan ke tahap selanjutnya 
yaitu pengujian efisiensi. Namun pada penelitian kali ini tahap pengembangan hanya sampai pada tahap develop atau pengembangan produk

\section{KESIMPULAN}

Berdasarkan dari uji ahli materi dan media serta uji kepraktisan maka dapat disimpulkan bahwa media pembelajaran yang

\section{DAFTAR RUJUKAN}

Auliah, A., \& Iwan, D. (2010). Pengembangan media pembelajaran berbasis hiperteks pada materi struktur atom dan sistem periodik. Jurnal Chemical, 11(1).

Daryanto. (2010). Media pembelajaran. Bandung: Satu Nusa.

Meintatiwi, E.Y., \& Masykuri, M. (2015). Pengembangan multimedia pembelajaran tutorial menggunakan software macromedia flash pada materi sifat keperiodikan unsur untuk pembelajaran kimia kelas X MIA SMA. Jurnal Pendidikan Kimia, 4(1).

Nisa, K., \& Mahardika, A.I. (2017). Pengembangan media pembelajaran berbantuan aplikasi autoplay media studio pada pokok bahasan fluida dinamis di SMA. Jurnal Ilmiah Pendidikan Fisika, 1(1).

Nurhasnawati. (2012). Media pembelajaran teori dan aplikasi pengembangan. Pekanbaru: Yayasan Pusaka Riau.

Nu'aimah, S., \& Kholis, N. (2016). Pengembangan media pembelajaran interaktif berbantuan software autoplay media studio pada mata pelajaran sensor dan aktuator di SMK Negeri 2 Bojonegoro. Jurnal Pendidikan Teknik Elektro, 5(2). telah dikembangkan dengan menggunakan aplikasi autoplay media studio mendapatkan penilaian sangat valid dari ahli materi dan media serta sangat praktis untuk digunakan berdasarkan penilaian dari guru kimia dan peserta didik, sehingga media dapat dilanjutkan ke proses pengembangan selanjutnya yaitu tahap disseminate atau penyebaran untuk mengetahui efisiensi media.

Pambudi, I.D. (2015). Pengembangan multimedia pengurangan risiko bencana (prb) berbantuan macromedia flash bagi siswa SD di wilayah rawan bencana. Elementary School, 2(1).

Pratama, Y., \& Yudha, A.A. (2017). Pengembangan media pembelajaran berbasis autoplay pada mata pelajaran menerapkan konsep elektronika komputer di SMK Negeri 1 Driyorejo. Jurnal Pendidikan Teknik Elektro, 6(1).

Shubhi, L.R., Widiyanti \& Yoto. (2015). Pengembangan media pembelajaran interaktif berbasis aplikasi autoplay media studio 8 pada materi turbin air program keahlian teknik pemesinan kelas $\mathrm{X}$ di SMK Nasonal Malang. Jurnal Pendidikan Profesional, 4(1).

Sugiyono. (2010). Metode Penelitian Pendidikan Pendekatan Keuantitatif, Kualitatif, dan $R \& D$. Bandung: Alfabeta.

Wijaya, I., \& Rakhmawati, L. (2015). Pengembangan media pembelajaran autoplay media studio pada mata pelajaran perekayasaan sistem audio di SMK Negeri 3 Surabaya. Jurnal Pendidikan Teknik Elektro, 4(3). 